\title{
PENGARUH PENAMBAHAN SODA DAN ASAM JAWA (Tamarindus indicia L.) PADA MINUMAN TRADISIONAL KUNYIT ASEM TERHADAP DAYA TERIMA KONSUMEN BERDASARKAN MUTU DAN ORGANOLEPTIKNYA
}

The Effect Of Addition Of Java Acid And Soda (Tamarindus indicia L.) In Kunyit Asem Traditional Drinking To Consumer Receiving Based On Quality And Its Organoleptic

\author{
Firduasi Puji Suryana', Dimas Hari Purnomo, Ana Ummu Mas'ulah", \\ Wike Adhi Anggono ${ }^{2}$, Rekna Wahyuni ${ }^{3}$ \\ ${ }^{1}$ Mahasiswa ITP, Universitas Yudharta Pasuruan \\ ${ }^{2}$ Staff FT, Universitas Yudharta Pasuruan \\ ${ }^{3}$ Dosen ITP, Universitas Yudharta Pasuruan \\ Email:wike73@gmail.com
}

\begin{abstract}
ABSTRAK
Kunyit asam merupakan minuman tradisioan yang memiliki manfaat antioksidan, antimikroba, sumber protein, serta vitamin A. penambahan carbonated (soda) bertujuan untuk memberikan inovasi baru pada pembuatan minuman tradisional. Penelitian ini bertujuan mengetahui penambahan carbonaten (soda) dan asam jawa (Tamarindus indicia L.) yang paling tepat terhadap daya terima konsumen berdasarkan mutu dan organoleptiknya. Rancangan Percobaan menggunakan Rancangan Acak Kelompok (RAK) dengan 2 Faktor. Faktor pertama penambahan soda (2.5 gr, 5 gr) dan faktor kedua penambahan asam jawa ( 2 gr, 4 gr, 6 gr). Masing-masing diulang sebanyak 3 kali sehingga diperoleh 18 percobaan. Data diperoleh dari pengamatan karakteristik kimia dan organoleptik. Uji kimia meliputi, kadar protein, PH. Sedangkan sifat organoleptik diperoleh dari uji organoleptik kesukaan (hedonic) skor menggunaan 20 orang panelis meliputi rasa, aroma, bau, warna. Data dari pengamatan sifat fisik, kimia dilakuakan analisis ragam ANOVA 5\% dan 1\%. Apabila ditemukan pengaruh nyata terhadap salah satu perlakuan maka dilanjutkan dengan uji beda nyata terkecil (BNT 5\%). Untuk uji organoleptik dilakukan analisis menggunakan uji Friedman. Perlakuan terbaik menggunakan metode metode indeks efektifitas de Garmo et al., (1984) yang dimodifikasi oleh Susrini (2003). perlakuan terbaik didapatkan hasil perlakukan terbaik pada penambahan soda 30\% dan asam jawa 15 g/liter (S1A3) dengan perolehan nilai 0.900. dengan rincian protein $1.55 \%, \mathrm{pH} \mathrm{8}$, Rasa 3.45 (netral), Aroma 4.55 (sangat suka), warna 3.65 (Suka).
\end{abstract}

Kata Kunci : Kunyit, Asam, Soda, konsumen

\section{ABSTRACT}

Acidic turmeric is a traditional beverage that has antioxidant, antimicrobial, protein sources and vitamin A. The addition of carbonated (soda) aims to provide new innovations in the manufacture of traditional drinks. This study aims to determine the most appropriate addition of carbonaten (soda) and tamarind (Tamarindus indicia L.) to consumer acceptance based on the quality and organoleptic. The design of the experiment used a randomized block design (RBD) with 2 factors. The first factor is the addition of soda (2.5 gr, $5 \mathrm{gr})$ and the second factor for adding tamarind (2 $\mathrm{gr}, 4 \mathrm{gr}, 6$ gr). Each was repeated 3 times to obtain 18 experiments. Data obtained from observations of chemical and organoleptic characteristics. Chemical tests include, 
protein content, $\mathrm{PH}$. While the organoleptic properties obtained from the favorite organoleptic (hedonic) test scores used 20 panelists including taste, aroma, smell, color. Data from observing physical properties, chemistry carried out an analysis of variance of ANOVA 5\% and 1\%. If there is a real effect on one treatment, then it will be followed by the smallest real difference test $(5 \%$ BNT). The organoleptic test was analyzed using the Friedman test. The best treatment uses the method of index effectiveness method de Garmo et al. (1984) modified by Susrini (2003). the best treatment obtained the best treatment results in the addition of 30\% soda and tamarind acid $15 \mathrm{~g} /$ liter (S1A3) with the acquisition value of 0.900. with details of protein $1.55 \%$, pH 8, taste 3.45 (neutral), Aroma 4.55 (very like), color 3.65 (likes).

Keywords: Turmeric, Acid, Soda, consumers

\section{PENDAHULUAN}

\section{Latar Belakang}

Kandungan pada kunyit yang memberikan warna dan sifat fungsional adalah kurkuminoid. Senyawa ini merupakan salah satu jenis antioksidan dan berkhasiat antara lain sebagai hipokolesteromik, kolagogum, koleretik, bakteriostatik, spasmolitik, anti hepatotoksik, dan anti inflamasi. Selain kurkumin, kandungan 1-turmeron pada rimpang temu lawak berkhasiat untuk mengobati berbagai penyakit (Winarti dan Nurdjanah, 2005).

Asam jawa merupakan tanaman yang digunakan pada obat tradisional untuk mengobati berbagai penyakit seperti demam, disentri, dan gangguan pencernaan (Kobayashi et al., 1996; Ferrara, 2005). Penelitian farmakologis menunjukkan bahwa asam jawa mempunyai aktivitas antibakteri, antikapang, efek hipoglikemik, efek hipokolesterolemik, anti- peradangan, hipolipomik, dan aktivitas antioksidan (Ferrara, 2005). Hasil ekstraksi metanol menunjukkan bahwa asam jawa mengandung triterpen yaitu lupanone dan lupeol (Shehla Imam et al., 2007).

Minuman berkarbonasi merupakan minuman yang memasukkan gas-gas $\mathrm{CO} 2$ (karbondioksida) ke dalam minuman sehingga memiliki penampakan bergelembung-gelembung yang memberi kesan segar (Rara, 2008).

Berdasarkan manfaat dari kuyit, asam, dan soda, maka perlu diterapkan kedalam sebuah produk minuman berkarbonasi terhadap daya terima konsumen berdasarkan mutu dan organoleptiknya.

Berdasarkan uraian diatas maka perlu adanya sebuah penelitian mengenai Pengaruh Penambahan Carbonated (Soda) dan Asam Jawa (Tamarindus indicia L.) Pada Minuman Tradisional Kunyit Asem 
Terhadap Daya Terima Konsumen hijau. Berdasarkan warnanya, kunyit Berdasarkan Mutu Dan Organoleptiknya. dibagi menjadi dua jenis yaitu kunyit putih dan kunyit kuning (Nur, 2010).

\section{Rumusan Masalah}

Berdasarkan uraian-uraian di atas maka perumusan masalah dalam proposal ini adalah berapakah penambahan Carbaonated (soda) dan asam jawa (Tamarindus indicia L.) pada minuman tradisional kunyit asam terhadap daya terima konsumen berdasakan mutu dan organoleptiknya?.

\section{Tujuan Penelitian}

Penelitian ini bertujuan untuk mengetahui penambahan carbonaten (soda) dan asam jawa (Tamarindus indicia L.) yang paling tepat terhadap daya terima konsumen berdasarkan mutu dan organoleptiknya.

\section{LANDASAN TEORI}

\section{Kunyit}

Tanaman kunyit merupakan komoditas rimpang-rimpangan yang kesediaannya melimpah dan mudah dijumpai di Indonesia. Menurut Meiyanto (2003), kunyit merupakan tanaman rimpang-rimpangan sejenis jahe, bentuknya seperti tabung, berwarna putih hingga kuning dan daunnya berwarna

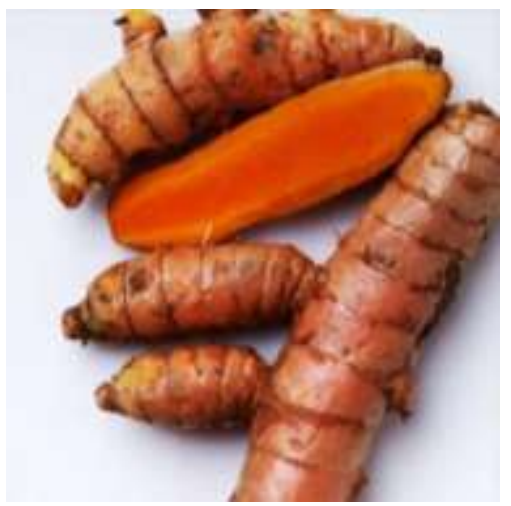

Gambar 2.1 Kunyit (Curcuma domestica

Val.)

Kandungan pada kunyit yang memberikan warna dan sifat fungsional adalah kurkuminoid. Senyawa ini merupakan salah satu jenis antioksidan dan berkhasiat antara lain sebagai hipokolesteromik, kolagogum, koleretik, bakteriostatik, spasmolitik, antihepatotoksik, dan anti- inflamasi. Selain kurkumin, kandungan 1-turmeron pada rimpang temu lawak berkhasiat untuk mengobati berbagai penyakit (Winarti dan Nurdjanah, 2005).

Berikut ini merupakan beberapa manfaat kunyit bagi kesehatan dan cara penyajiannya (Jawa Pos, 2003) :

1) Mencegah diabetes mellitus

2) Mengobati usus buntu

3) Mempermudah proses persalinan

4) Menyapih bayi 
5) Mengobati sariawan

6) Menambah kadar darah merah

7) Mengobati amandel

8) Mengobati gatal-gatal

9) Mengobati jerawat

10) Menghilangkan bau badan tidak sedap

\section{Asam Jawa (Tamarindus indicia L.)}

Asam jawa merupakan famili dikotiledon yang termasuk ke dalam famili Leguminoceae sub family Caesalpiniaceae (Lewis et al., 2005). Pulp asam jawa digunakan untuk minuman dan di India merupakan sumber protein yang murah (Kumar et al., 1991). Asam jawa juga mengandung protein yang tinggi dengan berbagai jenis asam amino esensial, serta mengandung karbohidrat sebagai sumber energi dan kaya dengan mineral seperti kalium, fosfor, kalsium, dan magnesium. Juga mengandung sejumlah kecil vitamin A (Khanzada et al., 2008).

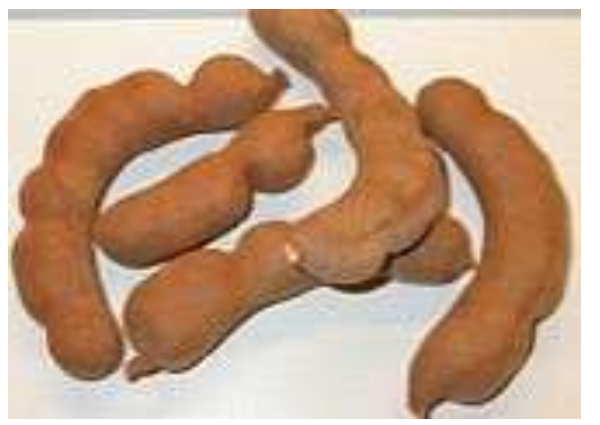

Gambar 2.2 Buah Asam Jawa
Asam jawa merupakan tanaman yang digunakan pada obat tradisional untuk mengobati berbagai penyakit seperti demam, disentri, dan gangguan pencernaan (Kobayashi et al., 1996; Ferrara, 2005). Penelitian farmakologis menunjukkan bahwa asam jawa mempunyai aktivitas antibakteri, antikapang, efek hipoglikemik, efek hipokolesterolemik, anti- peradangan, hipolipomik, dan aktivitas antioksidan (Ferrara, 2005). Hasil ekstraksi metanol menunjukkan bahwa asam jawa mengandung triterpen yaitu lupanone dan lupeol (Shehla Imam et al., 2007).

\section{Karbonasi (Soda)}

Minuman berkarbonasi merupakan minuman yang memasukkan gas-gas $\mathrm{CO} 2$ (karbondioksida) ke dalam minuman sehingga memiliki penampakan bergelembung-gelembung yang memberi kesan segar (Rara, 2008). Karbondioksida yang dilarutkan ke dalam air, menyebabkan air menjadi berbusa. Air berkarbonasi yang juga dikenal sebagai air soda, merupakan komponen utama dalam pembuatan minuman ringan. Proses melarutkan gas $\mathrm{CO} 2$ disebut karbonasi, yang dapat membentuk asam karbonat (memiliki rumus kimia (H2CO3) (Zentimer, 2007). 


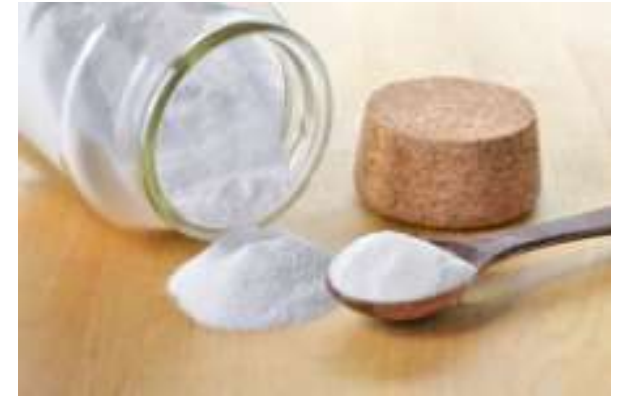

Gambar 2.3 Soda

\section{Minuman Tradisional Kunyit Asam}

Minuman kunyit asam merupakan

salah satu jenis minuman tradisional yang sudah sangat populer di masyarakat, khususnya daerah Jawa. Minuman ini merupakan suatu minuman yang dahulu dikenal sebagai jamu tetapi karena kemajuan zaman dan efek yang ditimbulkan oleh minuman ini, saat ini minuman kunyit asam tidak dikenal sebagai jamu lagi. Minuman ini berbahan baku utama kunyit dan asam. Saat ini minuman kunyit asam bisa diperoleh dengan jalan membuat sendiri atau membeli produk jadi yang diproduksi pabrik (Olivia, et al., 2006)

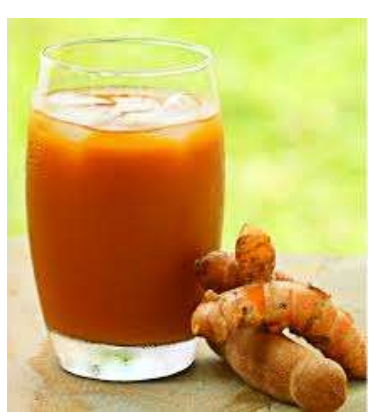

Gambar 2.4 Minuman Kunyit Asam

Minuman kunyit asam yang beredar di masyarakat biasanya terdiri dari setengah kilogram kunyit, setengah kilogram asam jawa, seperempat kilogram gula jawa, dan dua liter air. Kunyit yang telah dipersiapkan harus dibersihkan, diparut, kemudian diperas untuk diambil airnya. Air kunyit yang diperoleh, direbus dan dimasukkan asam jawa, air, serta gula jawa. Setelah itu harus didihkan dan akan diperoleh minuman kunyit asam (Dinda, 2007).

\section{METODE PENELITIAN}

\section{Tempat Penelitian}

Penelitian ini dilakukan di

Laboratorium Universitas Yudharta

Pasuruan

\section{Alat dan Bahan}

Bahan baku pembuatan minuman kunyit asam adalah rimpang kunyit, daging buah asam jawa, gula, asam citrad, air, garam, dan soda.

Peralatan yang digunakan : parut, baskom, saringan, kain kasa, blander, pisau, kulkas.

\section{Rancangan Percobaan}

Percobaan dilakukan dengan menggunakan rancangan acak kelompok (RAK) dengan 6 perlakuan dan masingmasing perlakuan diulang sebanyak 3 kali. 
Secara lengkap perlakuan yang diberikan adalah sebagai berikut :

S1A1 = Penambahan soda $30 \%$ dan asam 5 gr : 1 Liter

$\mathrm{S} 1 \mathrm{~A} 2=$ Penambahan soda $30 \%$ dan asam 10 gr : 1 Liter

S1A3 = Penambahan soda $30 \%$ dan asam

15 gr : 1 Liter

S2A1 = Penambahan soda $60 \%$ dan asam

$5 \mathrm{gr}$ : 1 Liter

S2A2 $=$ Penambahan soda $60 \%$ dan asam

10 gr : 1 Liter

S2A3 $=$ Penambahan soda $60 \%$ dan asam

15 gr : 1 Liter

Sehingga dari penelitian diatas diperoleh 18 kali percobaan

\section{Pengumpulan data}

Data diperoleh dari pengamatan karakteristik kimia dan organoleptik. Uji kimia meliputi, kadar protein, PH. Sedangkan sifat organoleptik diperoleh dari uji organoleptik kesukaan (hedonic) skor menggunaan 20 orang panelis meliputi rasa, aroma, bau, warna.

\section{Analisa Data}

Data dari pengamatan sifat fisik, kimia dilakuakan analisis ragam ANOVA $5 \%$ dan $1 \%$. Apabila ditemukan pengaruh nyata terhadap salah satu perlakuan maka dilanjutkan dengan uji beda nyata terkecil
(BNT 5\%). Untuk uji organoleptik dilakukan analisis menggunakan uji Friedman. Perlakuan terbaik menggunakan metode metode indeks efektifitas de Garmo et al., (1984) yang dimodifikasi oleh Susrini (2003).

\section{HASIL YANG DICAPAI}

\section{Kadar Protein}

Hasil penelitian menunjukkan bahwa penambahan buah asam disetiap perlakuan menunjukkan adanya peningkatan jumlah kadar protein. Hal ini disebabkan karena asam jawa mengandung protein yang tinggi dengan berbagai jenis asam amino esensial (Khanzada et al., 2008). Pulp asam jawa digunakan untuk minuman dan di India merupakan sumber protein yang murah (Kumar et al., 1991).

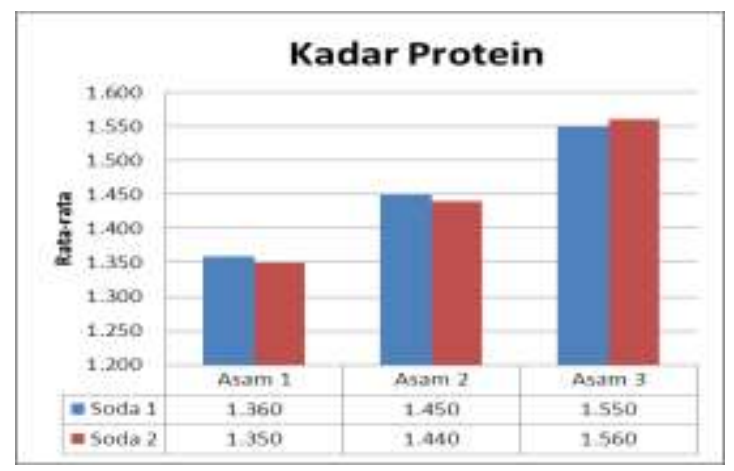

\section{Gambar 4.1 Kadar Protein}

Sedangkan penambahan soda tidak menunjukkan adanya peningkatan kadar protein. Hal ini dikarenakan soda minuman adalah hasil pelarutan antara 
$\mathrm{CO} 2$ dengan $\mathrm{H} 2 \mathrm{O}$ sehingga terbentuk H2CO3 Soda Minuman dan tidak ada unsur proteinnya. (wikipedia, 2017). Nilai tertinggi terdapat pada perlakuan S2A3 dengan kadar Protein $1.56 \mathrm{~g}$.

\section{Kadar pH}

Penambahan buah asam jawa menunjukkan bahwa adanya peningkatan pH pada minuman kunyit asam berkarbonasi. Hal ini dikarenakan buah asam jawa memiliki pH 8-9 (basa).

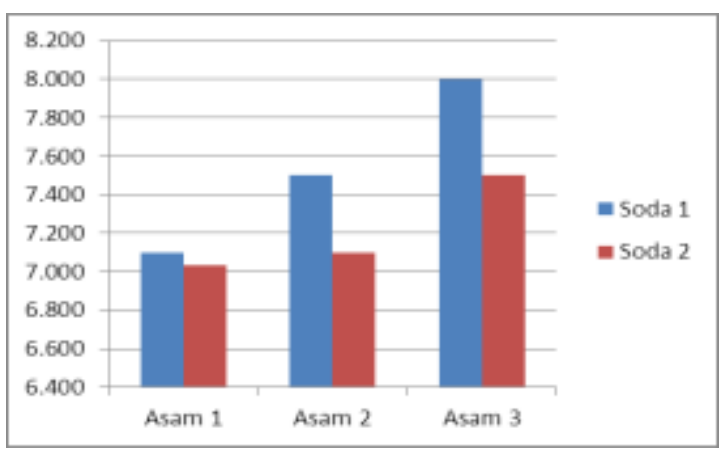

Gambar 4.2 Kadar pH

Sementara penambahan

soda

menunjukkan penurunan $\mathrm{pH}$. Hal ini dikarenakan bahwa soda memiliki sifat asam, sehingga semakin banyak penambahan soda pada kunyit asam akan mengakibatkan minuman tersebut mengalami penurunan PH. Senyawa penyusun dari soda minuman adalah $\mathrm{H} 2 \mathrm{CO} 3$ yang biasa disebut asam karbonat yang bersifat asam. Nilai tertinggi terletak pada perlakuan S1A3 dengan pH 8.

\section{Organoleptik Rasa}

Hasil uji organoleptik rasa menunjukkan bahwa panelis menyukai setiap penambahan asam jawa sebanyak 10 $\mathrm{g} /$ liter dari pada penambahan $5 \mathrm{~g} /$ liter dan $15 \mathrm{~g} /$ liter.

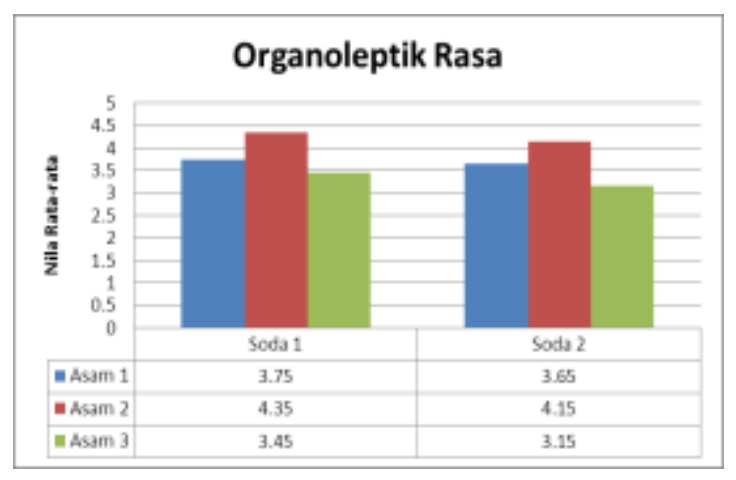

Gambar 4.3 Hasil Uji Organoleptik Rasa

Sedangkan pada perlakuan penambahan soda, panelis lebih menyukai perlakuan penambahan soda sebanyak $30 \%$ dibandingkan dengan penambahan $60 \%$. Nilai tertinggi terletak pada perlakuan S1A2 dengan nilai 4.35 (suka)

\section{Organoleptik Aroma}

Hasil uji organoleptik Aroma menunjukkan bahwa panelis menyukai setiap penambahan asam jawa sebanyak $15 \mathrm{~g} /$ liter dari pada penambahan $5 \mathrm{~g} /$ liter dan $10 \mathrm{~g} / \mathrm{liter}$. 




Gambar 4.4 Hasil Uji Organoleptik

Aroma

Sedangkan pada perlakuan penambahan soda, panelis lebih menyukai perlakuan penambahan soda sebanyak $30 \%$ dibandingkan dengan penambahan $60 \%$. Nilai tertinggi terletak pada perlakuan S1A3 dengan nilai 4.55 (sangat suka).

\section{Organloptik Warna}

Hasil uji organoleptik warna menunjukkan bahwa panelis menyukai setiap penambahan asam jawa sebanyak $5 \mathrm{~g} /$ liter dari pada penambahan $10 \mathrm{~g} /$ liter dan 15 g/liter.

Tabel 4.6 Hasil Analis Kimia dan Organoleptik

\begin{tabular}{|l|r|r|r|r|r|}
\hline & \multicolumn{1}{|c|}{ Protein } & \multicolumn{1}{c|}{ PH } & \multicolumn{1}{c|}{ Rasa } & \multicolumn{1}{c|}{ Aroma } & Warna \\
\hline \hline S1A1 & 1.360 & 7.100 & 3.750 & 4.350 & 4.350 \\
\hline S1A2 & 1.450 & 7.500 & 4.350 & 4.450 & 4.250 \\
\hline S1A3 & 1.550 & 8.000 & 3.450 & 4.550 & 3.650 \\
\hline S2A1 & 1.350 & 7.033 & 3.650 & 4.250 & 4.300 \\
\hline S2A2 & 1.440 & 7.100 & 4.150 & 4.450 & 4.250 \\
\hline S2A3 & 1.560 & 7.500 & 3.150 & 4.500 & 3.500 \\
\hline Ntj & 1.350 & 7.033 & 3.450 & 4.250 & 3.650 \\
\hline Ntb & 1.550 & 8.000 & 4.350 & 4.550 & 4.350 \\
\hline
\end{tabular}


Tabel 4.7 Pencarian Perlakuan Terbaik

\begin{tabular}{|c|c|c|c|c|c|c|c|c|c|c|c|c|c|}
\hline \multirow{3}{*}{ Parameter } & \multirow{3}{*}{$\begin{array}{l}\text { Bobot } \\
\text { Para } \\
\text { meter }\end{array}$} & \multicolumn{12}{|c|}{ PERLAKUAN } \\
\hline & & \multicolumn{2}{|c|}{ S1A1 } & \multicolumn{2}{|c|}{ S1A2 } & \multicolumn{2}{|c|}{ S1A3 } & \multicolumn{2}{|c|}{ S2A1 } & \multicolumn{2}{|c|}{ S2A2 } & \multicolumn{2}{|c|}{ S2A3 } \\
\hline & & $\mathrm{NE}$ & NP & $\mathrm{NE}$ & NP & $\mathrm{NE}$ & NP & $\mathrm{NE}$ & NP & $\mathrm{NE}$ & NP & $\mathrm{NE}$ & NP \\
\hline Protein & 0.312 & 0.048 & 0.015 & 0.476 & 0.149 & 0.952 & 0.297 & 0.000 & 0.000 & 0.429 & 0.134 & 1.000 & 0.312 \\
\hline $\mathrm{PH}$ & 0.086 & 0.069 & 0.006 & 0.483 & 0.042 & 1.000 & 0.086 & 0.000 & 0.000 & 0.069 & 0.006 & 0.483 & 0.042 \\
\hline Rasa & 0.269 & 0.069 & 0.019 & 0.483 & 0.130 & 1.000 & 0.269 & 0.000 & 0.000 & 0.069 & 0.019 & 0.483 & 0.130 \\
\hline Aroma & 0.113 & 0.500 & 0.056 & 1.000 & 0.113 & 0.250 & 0.028 & 0.417 & 0.047 & 0.833 & 0.094 & 0.000 & 0.000 \\
\hline Warna & 0.219 & 0.333 & 0.073 & 0.667 & 0.146 & 1.000 & 0.219 & 0.000 & 0.000 & 0.667 & 0.146 & 0.833 & 0.183 \\
\hline Total & 1.000 & & 0.169 & & 0.579 & & 0.900 & & 0.047 & & 0.399 & & 0.667 \\
\hline
\end{tabular}

berdasarkan mutu dan organoleptiknya

Berdasarkan hasil uji Indek Efektifitas diperoleh perlakuan terbaik terdapat pada penambahan soda $30 \%$ dan asam jawa 15 g/liter (S1A3) dengan perolehan nilai 0.900. dengan rincian protein $1.55 \%, \mathrm{pH}$ 8, Rasa 3.45 (netral), Aroma 4.55 (sangat suka), warna 3.65 (Suka).

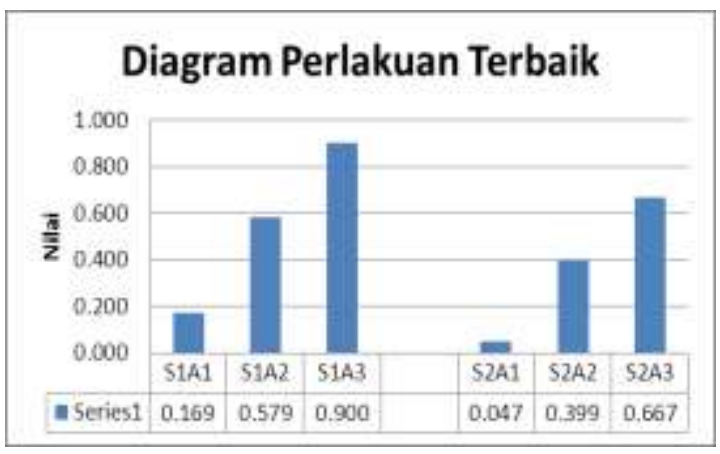

Gambar 4.6 Indeks Efektifitas

\section{KESIMPULAN}

Dari analisa dapat disimpulkan bahwa perlakuan terbaik pada Penelitian Pengaruh Penambahan Carbonated (Soda) Dan Asam Jawa (Tamarindus indicia L.) pada minuman tradisional kunyit asem terhadap daya terima konsumen didapatkan hasil perlakukan terbaik pada penambahan soda $30 \%$ dan asam jawa 15 g/liter (S1A3) dengan perolehan nilai 0.900. dengan rincian protein $1.55 \%, \mathrm{pH}$ 8, Rasa 3.45 (netral), Aroma 4.55 (sangat suka), warna 3.65 (Suka).

\section{DAFTAR PUSTAKA}

Dinda E., (2007). "Kunir Asem" The Herbal Medicine. http://embundinda.multiply.com/jou rnal/item/28/Kunir_Asem_The_Her bal_Medicine. diakses tanggal 25 Nopember 2016

Erlianawati, (2014). Pengaruh minuman berkarbonasi terhadap Kadar glukosa darah mencit (Mus musculus). Naskah Publikasi Fakultas Keguruan Dan Ilmu Pendidikan Universitas Muhammmadiyah ; Surakarta

Lewis, G.B., B. Schrire, Mackinder and M. Lock. (2005). Legumes of the World. Royal Botanic Gardens, Kew 
Meiyanto, Edy. (2003). Kunyit Asam Segar Menyehatkan. Artikel Ilmiah. Jawa Pos Edisi 24 Maret 2003.

Nur, M., Estiasih, T., Mochamad N., Jaya MM., (2010). Modul Aneka Produk Olahan Kunyit Asam, Universitas Brawijaya; Malang

Olivia F., Alam S. and Hadibroto I. (2006). Seluk Beluk Food Supplement. Jakarta: Penerbit PT Gramedia Pustaka Utama, p: 166.

Rara. (2008). Minuman Ringan: Kenikmatan Membawa Sengsara. www.depkes.go.id. Diakses tanggal 25 Oktober 2016
Wikipedia, (2017). Asam Karbonat. https://id.wikipedia.org/wiki/Asam_ karbonat, diakses tangaal 30 Juli 2017

Winarti, C. dan N. Nurdjanah. (2005). Peluang Tanaman Rempah dan Obat sebagai Sumber Pangan Fungsional. Jurnal Litbang Pertanian 24(2): $47-$ 55

Zentimer, Suyetmi. (2007). Pengaruh Konsentrasi Natrium Benzoat dan Lama Penyimpanan terhadap Mutu Minuman Sari Buah Sirsak (Anona muricata L) Berkarbonasi. Skripsi. Surakarta: Universitas Sumatra Utara. 